\title{
Classics revisited: key articles from the Canadian Journal of Anesthesia, 1954-2013
}

\author{
Donald R. Miller, MD • Hilary P. Grocott, MD
}

Received: 1 October 2013/Accepted: 11 October 2013/Published online: 19 November 2013

(C) Canadian Anesthesiologists' Society 2013

The Canadian Journal of Anesthesia (the Journal) has a long and rich history beginning with the first issue of its legacy, Canadian Anaesthetists' Society Journal, published in July, 1954. In 1987, the name of the Journal was changed to the Canadian Journal of Anaesthesia/Journal canadien d'anesthésie) to reflect the fact that the scope and readership of the Journal, though still an important outward representation of the Canadian Anesthesiologists' Society (CAS), were becoming increasingly international. The first issue included summaries of presentations at the annual and regional meetings of the CAS held in 1954. The founding Editor-in-Chief, Dr. Roderick Gordon, wrote the following in the first published editorial: "This journal will provide a suitable Canadian medium for the presentations of original work by Canadian anaesthetists and a means of communicating our news and views to our Canadian colleagues, and to others who may take some interest in them. Given the continued support of the anaesthetists of Canada, our new publication should maintain the standard of excellence set by its two predecessors [the News Letter of the Canadian Anaesthetists' Society and the Proceedings of the Society]." ${ }^{1}$ Former Editors-in-Chief, Dr. R.A. Gordon, Dr. D.B. Craig, and Dr. D.R. Bevan captured the history and origins of the first half century of the Journal in a special article entitled The Society's Journal from: "Watching Closely Those Who Sleep: A History of the Canadian

D. R. Miller, MD ( $₫)$

Department of Anesthesiology, The Ottawa Hospital and University of Ottawa, General Campus CCW 1401, 501 Smyth Road, Ottawa, ON K1H 8L6, Canada

e-mail: dmiller@ottawahospital.on.ca

H. P. Grocott, MD

Department of Anesthesia \& Perioperative Medicine, University of Manitoba, Winnipeg, MB, Canada
Anaesthesiologists' Society 1943-93".2 Developments during the past nine years (2005-13) are summarized in a recent editorial. $^{3}$

As part of the Journal's $60^{\text {th }}$ anniversary Diamond Jubilee Celebration, Volume 61 of the Journal will highlight classic and seminal articles (available from the online archives at: www.springer.com/12630) over the course of 2014. In all, 24 distinctive articles were selected from earlier issues of the Journal, in part from key manuscripts listed in the article by Drs. Gordon et al. ${ }^{2}$ and in part from "the editor's picks" selected by the 2013 editorial team (Miller DR, Donati F, Mazer D, Beattie S, Brasher P). The "classic articles" were selected on the basis of their overall novelty at the time, their scientific merit, and their subsequent citation indices, making them influential landmark articles that advanced science and clinical practice.

In the first featured article in this series, A harbinger of modern anesthesia, ${ }^{4}$ Dr. Edmond I. Eger II from the Department of Anesthesia and Perioperative Care, University of California, San Francisco, CA, provides expert commentary on a seminal article by Tsutomu Oyama entitled Effects of halothane anaesthesia and surgery on adrenocortical function in man (Can Anaesth Soc J 1968; 15: 258-66). Dr. Eger-who introduced the term "minimal alveolar concentration" (MAC) in his own landmark paper in 1965-explains that Dr. Oyama undertook his study "to investigate whether or not preanesthetic medication and halothane anesthesia affect adrenal cortical function in man" and concluded that "premedication decreased corticosteroids, and in the absence of an inducing dose of thiopental, induction of anesthesia with halothane and nitrous oxide increased corticosteroids." This work is significant because many prior studies examining the effects of anesthesia on 
corticosteroid metabolism suffered from the confounding effects of surgery. Part of Oyama's considerable contribution was to isolate the time period prior to surgery so as to distinguish the isolated effects of the anesthetic agents themselves.

In the second featured article in this issue, Dr. Robin Cox from the University of Calgary, Alberta, provides critical commentary on the article entitled Epidural anaesthesia in infants and children ${ }^{5}$ by Dr. Francis Ruston. Dr. Ruston investigated the use of single-shot epidural anesthesia in a series of 44 infants and children anesthetized over a time span from 1949-54. The report describes the indications and efficacy of this technique with a detailed description of the management of these patients, including clinical tips and suggestions that remain relevant to the present day. Sixty years after this original publication, the use of regional techniques in children continues to expand and evolve.

Watch for other featured articles in future issues this coming year, including one of the original articles from 1969 describing the hereditary aspects of malignant hyperthermia and another article from 1978 describing the effects of subanesthetic concentrations of halothane on regulation of ventilation. The latter was a seminal work showing that low doses of halothane at 0.05 and 0.1 MAC markedly reduce ventilatory responses to hypoxemia. The results of this work remain relevant to patient care in postanesthesia care units.

It is our sincere hope that this series of special articles celebrating 60 years of Journal publications will captivate our readers' interests as well as illustrate our Journal's ongoing mission: "Excellence in research and knowledge translation in anesthesia, pain, perioperative medicine and critical care".

\section{Revisitons les classiques: Articles clés du Journal canadien d'anesthésie, 1954-2013}

Le Journal canadien d'anesthésie (le Journal) est tributaire d'une longue et riche histoire, commençant avec le premier numéro de son ancêtre, le Journal de la Société canadienne des anesthésistes, publié en juillet 1954. En 1987, le Journal a été rebaptisé pour devenir le Journal canadien d'anesthésie / Canadian Journal of Anaesthesia; ce nouveau titre avait pour objectif de refléter que le Journal, tout en continuant à représenter la Société canadienne des anesthésiologistes (SCA) à l'extérieur, possédait désormais une portée et un lectorat de plus en plus internationaux. Le premier numéro de 1954 était constitué de résumés de présentations des congrès annuel et régionaux de la SCA tenus la même année. Dans le premier éditorial publié, le rédacteur en chef et fondateur de la revue, le Dr Roderick Gordon, écrivait: « $\mathrm{Ce}$ journal fournira un organe canadien approprié à la diffusion de travaux originaux d'anesthésistes canadiens et un moyen de communiquer nos nouvelles et nos opinions à nos collègues canadiens et à d'autres personnes qui pourraient s'y intéresser. Avec l'appui soutenu des anesthésistes du Canada, notre nouvelle publication devrait maintenir le niveau d'excellence établie par ses deux prédécesseurs [le Bulletin de nouvelles (News Letter) de la Société canadienne des anesthésistes et les Actes de conférence (Proceedings) de la Société]. » Quelques-uns des anciens rédacteurs en chef, nommément les Drs R.A. Gordon, D.B. Craig, et D.R. Bevan, ont relaté l'histoire et les origines du premier demi-siècle du Journal dans un article spécial intitulé The Society's Journal, paru dans: «Watching Closely Those Who Sleep: A History of the Canadian Anaesthesiologists' Society 1943-93» («Veiller sur ceux qui dorment: une histoire de la Société canadienne des anesthésiologistes, 1943-1993 »). ${ }^{2}$ Les développements des neuf dernières années (2005-13) ont quant à eux été résumés dans un éditorial récent. ${ }^{3}$

Dans le cadre des célébrations entourant le $60^{\mathrm{e}}$ anniversaire du Journal, le volume 61 mettra à l'honneur certains des articles classiques et incontournables du Journal (disponibles à partir des archives en ligne au: www.springer.com/12630) tout au long de 2014. Au total, 24 articles distincts ont été retenus des numéros plus anciens du Journal. Certains font partie des manuscrits clés énumérés dans l'article de Dr Gordon et coll., ${ }^{2}$ alors que d'autres sont cités dans les « choix de la rédaction » retenus par l'équipe rédactionnelle de 2013 (Miller DR, Donati F, Mazer D, Beattie S, Brasher P). Les « classiques » ont été choisis sur la base de leur degré global d'innovation à l'époque de leur publication, de leur mérite scientifique et de leurs indices subséquents de citation, ce qui en fait des articles incontournables influents qui ont permis de faire progresser la science et la pratique clinique.

Dans le premier article de cette série, A harbinger of modern anesthesia, le Dr Edmond I. Eger II, du département d'anesthésie et de soins périopératoires de l'Université de Californie à San Francisco, CA, présente un commentaire expert sur un article phare de Tsutomu Oyama intitulé Effects of halothane anaesthesia and surgery on adrenocortical function in man (Can Anaesth Soc J 1968; 15: 258-66). Le Dr Eger - qui a introduit le concept de « concentration alvéolaire minimale » (MAC) dans son propre article incontournable de 1965 - explique que le Dr Oyama a entrepris son étude « afin d'examiner si la médication préanesthésique et l'anesthésie à l'halothane 
affectaient ou non la fonction corticosurrénalienne chez l'humain » et qu'il a conclu que «la prémédication réduisait les corticostéroïdes, et en l'absence d'une dose d'induction de thiopental, l'induction de l'anesthésie à l'halothane et au protoxyde d'azote augmentait les corticostéroïdes. » Ces travaux sont importants parce que de nombreuses études publiées précédemment au sujet des effets de l'anesthésie sur le métabolisme des corticostéroïdes étaient affectées par les effets de confusion liés à la chirurgie. L'une des composantes de la contribution substantielle d'Oyama a été d'isoler la période temporelle précédant la chirurgie afin de distinguer les effets isolés des agents anesthésiques eux-mêmes.

Dans le deuxième article présenté dans ce numéro, le Dr Robin Cox, de l'Université de Calgary en Alberta, propose un commentaire critique de l'article intitulé Epidural anaesthesia in infants and children $^{5}$ du Dr Francis Ruston. Le Dr Ruston a étudié l'utilisation d'une anesthésie péridurale par injection unique dans une série portant sur 44 nourrissons et enfants anesthésiés entre 1949 et 1954. Le compte rendu décrit les indications et l'efficacité de cette technique en fournissant une description détaillée de la prise en charge de ces patients, y compris des astuces et des suggestions cliniques qui sont toujours aussi pertinentes aujourd'hui. Soixante ans après cette publication originale, l'utilisation de techniques régionales chez l'enfant ne cesse de croître et d'évoluer.

Gardez l'œil ouvert pour repérer les articles présentés dans les numéros à venir de cette année, y compris l'un des articles originaux de 1969 décrivant les aspects héréditaires de l'hyperthermie maligne ainsi qu'un autre, datant de 1978, décrivant les effets de concentrations sous-anesthésiques d'halothane sur la régulation de la ventilation. Le second est un article précurseur montrant que de faibles doses d'halothane à 0,05 et 0,1 MAC réduisent de façon marquée la réponse ventilatoire à l'hypoxémie. Les résultats de ces travaux sont encore pertinents aux soins aux patients dans les salles de réveil.

Nous espérons sincèrement que cette série d'articles spéciaux célébrant 60 ans de publications du Journal saura captiver l'intérêt de nos lecteurs tout en illustrant la mission de notre Journal: "L'excellence en recherche et en transfert des connaissances liées à la pratique clinique de l'anesthésie, de la prise en charge de la douleur, de la médecine périopératoire et des soins critiques».

Competing interests None declared.

\section{References}

1. Gordon RA. "Editorial". Can Anaesth Soc J 1954; 1: iii.

2. Gordon RA, Craig DB, Bevan DR. The Society's Journal from: "Watching Closely Those Who Sleep: A History of the Canadian Anaesthesiologists' Society 1943-93". Can J Anaesth 1993; 40: 160-9 [Suppl].

3. Miller DR. A fond adieu and reflections on nine years at the helm of the Journal: 2005-2013. Can J Anesth 2013. doi:10.1007/ s12630-013-0046-0.

4. Eger II EI. From the Journal archives: A harbinger of modern anesthesia. Can J Anesth 2014: 61: this issue.

5. Cox R. From the Journal archives: Epidural anesthesia in young children: What have we learned in the past 60 years? Can J Anesth 2014; 61: this issue. 